\title{
SMART CITIES: UTOPIA OR NEOLIBERAL IDEOLOGY?
}

\begin{abstract}
This paper develops a critical understanding of the smart city by investigating the values and ideas that underpin this concept and how they are translated into practice. It suggests that, despite private companies and municipalities promoting the smart city as a revolutionary utopia, this utopia is, on the contrary, an expression of the neoliberal ideology. The case study of the Italian city of Genoa shows that the smart city utopia acts as a generator of a collective imaginary while promoting the interests of business elites and diverting the attention away from urgent urban problems, such as urbanization. The neoliberal ideology influences the framing of these problems by favoring business-led technological solutions rather than political and long-term urban planning. The study suggests that this business-led utopia has important implications in terms of accountability of the actors involved.
\end{abstract}

Keywords: smart city, utopia, ideology, hermeneutics, neoliberalism.

\section{Introduction}

There is a high level of agreement in the literature that there is as yet no common definition of a smart city (Cocchia, 2014; Baron, 2012; Caragliu et al., 2011; Angelidou, 2014; Neirotti et al., 2014). The increasing diffusion of models, standards and definitions of smart city creates ambiguity and makes it difficult to estimate to what extent the existing smart cities keep up with the expectations and the ideals claimed by the promoters of this paradigm (Anthopoulos, 2016).

Overall, the IT dimension appears central to the smart city (Carvalho, 2015; Mora et al., 2017) and the advocates of this urban paradigm highlight the benefits resulting from the adoption of technologies, techniques and visions, granting that these are "scientific, objective, commonsensical and apolitical" in nature (Kitchin, 2014, 132). According to IBM $(2011,2)$, a smart city is an "interconnected, instrumented and intelligent" city. The "smartness" of a city seems related to its capability of providing infrastructures and services that improve the lives of its citizens (Cretu, 2012). Pamula et al. (2013) define the smart city as a solution to problems such as aging of social infrastructure, $\mathrm{CO} 2$ emissions and urbanization. Meijer and Bolívar (2015) identify three constitutive elements of the smart city: smart technology, smart people and smart collaboration.

A growing critical literature has countered these optimistic rhetoric and largely celebratory tones (Hollands, 2015; Hollands, 2008; Greenfield, 2013; Vanolo, 2013; Kitchin, 2014; Marvin et al., 2015). Adopting a critical standpoint, this literature has analyzed the smart city as an expression of a neoliberal and market-led restructuring process of the urban space (Brenner and Theodore, 2002a; Brenner and Theodore, 2002b; Hollands, 2008; Peck and Tickell, 2002). The diffusion of new models of local governance based upon privatization and public-private partnerships, the exposure of municipalities to global competition, and the mobilization of an entrepreneurial ethos and discourse are among the most important traits of this "neoliberalization" (Brenner and Theodore, 2002b, 353) process. The literature has raised concerns about the growing role of private corporations in defining and making-up the smart city, thus alternately labelling the smart city as a "corporate smart city" (Hollands, 2015, 2), a "private city" (Adams, 2010, 6), and an "entrepreneurial city" (Harvey, 1989). Critical studies suggest that this business-driven development of smart city might result in a prioritization of business goals over social and economic ones, thus leading to social polarization and inequality (Brenner and Theodore, 2002b; Hollands, 2008). 
In line with previous studies (Anthopoulos, 2016; Angelidou, 2015; Ahvenniemi et al., 2017; Meijer and Bolívar, 2015), this paper tries to clarify the characteristics and ideas underpinning the smart city vision, with the belief that more critical reflection on the topic is needed (Marvin et al., 2015). The paper suggests that, despite private corporations and cities promoting the smart city as a revolutionary utopia, this paradigm is an expression of the neoliberal ideology. By developing a brief case study of Genoa, this study tries to support the theoretical points with empirical evidence - thus addressing a shortcoming of the critical literature, which requires more engagement with empirical research (Kitchin, 2014).

The paper is logically structured in five sections, with the next section (section 2) explaining the main concepts of our critical discourse (utopia and ideology) and contextualizing them within the ongoing debate on smart cities. Section 3 provides insights into the critical hermeneutics methodology adopted. Section 4 provides a brief case analysis of the smart city of Genoa and Section 5 presents our conclusions.

\section{Utopia and the neoliberal ideology}

The word utopia is from the Greek oủ ("not") and tóros ("place "), and it refers to an imaginary perfect place. The book of Deuteronomy offers a first example of the symbolic power of this conceptual construct. The book narrates that God did not allow Moses to enter the Promised Land, the prophet could only see it from a distance. The description of the Promised Land recalls the garden of the Eden and the apocalyptic vision "Then I saw a new heaven and a new earth, for the first heaven and the first earth had passed away, and the sea was no more" (Revelation 21:1). The Promised Land is described as the direction, the telos in the form of future/place to which humanity should strive and aspire. The act of seeing symbolizes an overcoming of space and time, the imagination of a world alternative to the existent. Utopia refers to this imaginary capacity that guides man's actions and aspirations.

In 1516, a book by Sir Thomas More uses the term utopia to describe an ideal island in which legal, political and economic systems allowed its community to live in harmony and in peace. Since then, the term utopia has been used to describe an imaginary project alternative to the existing social order, an ideal model of society (Campanella, 1602). The description of the State offered by Plato in the Republic can be considered

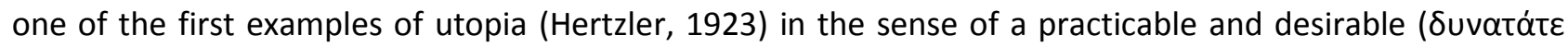

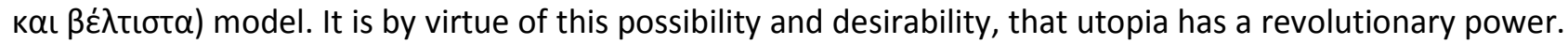
In this sense, the Marxist E. Bloch (1995) distinguishes the "abstract utopia" from the "concrete utopia", the latter referring to a project connected with reality that leads citizens forward into historical transformation and social revolution.

In recent decades, the concept of concrete utopia has been used to define the smart city initiatives (Söderström et al. 2014; Wiig, 2015; Datta, 2015; Watson, 2013; Vanolo, 2016; Marvin et al., 2015; Anthopoulos, 2016). On one hand, the advocates of this paradigm (public, private and not-for profit actors) describe the smart city as "a concrete utopia in an urban space at human scale" (Genoa Smart City Association, GSCA). It is common to read in newspapers slogans such us "welcome to the city of Utopia...in Florence, city of the digital Renaissance" (Ferrara, 2014) and "the notion of smart city has been attractive as a concrete utopia" (II Sole 24 ORE, 2014). The reference to utopia is clearly stated: "The major point of contact with the idea of smart cities is however in the New Atlantis of Bacon [...] In this city, science is sovereign" (Fuggetta, 2012). The description of smart city as a "common vision that provides citizens, 
business, and institutions with a 'high-level' goal on which to base potential sacrifices" (ABB, 2012, 37) reveals the eschatological character of this utopia.

On the other hand, critical studies suggest that, when translated into practice, the smart city utopia often conflicts with its aspirations. Wiig (2015) explains that a disconnection exists between the smart city concept and the translation of public policies into practice. Thus, "techno-utopian smart city solutions" (Wiig, 2015, 260) might become rhetorical devices mobilized to divert the attention away from the real problems of the citizenship. In the same vein, Watson (2013) suggests that there is a sharp contrast between the image of African cities boosted by the smart city rhetoric and the actual conditions of the population, the results of these fantasies being instead increasing social inequalities and marginalization.

This paper argues that a dialectic exists between utopia and ideology due to the inner connection of utopia to "authority and control" (Harvey, 2000, 163). The emergence of a utopia over alternative visions fixes a specific moral order (Vanolo, 2013; Harvey, 2000) and might lead to the transformation of utopia into ideology, the latter being an "imaginary transposition of the real conditions of existence" (Althusser, 1971). Ideology describes "a negative sense of illusory self-understanding which helps a dominant class to sustain and reproduce its power and control" (Nørreklit et al., 2006). Ideologies have a practical impact on daily life insofar as they produce a collective imaginary that reinforces existing systems of social domination while preventing the production of alternative imaginaries (Eagleton, 1996; Van Dijk, 1998). This paper suggests that the smart city utopia is a fundamental facet of the neoliberal contemporary ideology (Kornberger and Carter, 2010; Hackworth, 2007).

Neoliberalism is a macro-logical concept difficult to outline due to its hybrid character. Indeed, neoliberalism is never found in a pure form, but it is always mediated by the historical, economic and social context in which it emerges (Peck, 2013). A contrast may then exist between neoliberal ideology and "actual existing neoliberalism" (Peck, 2013, 146). This paper focuses on the ways in which the assumptions underpinning the neoliberal ideology have influenced the formulation of the smart city utopia and its translation into practice.

Fostered in the political arena by Thatcher and Reagan in the '80s, neoliberalism makes his appearance in the field of city government with the proposal of market mechanisms and managerialism as solutions to urban problems (Kornberger and Carter, 2010; Harvey, 2005). In this specific setting, neoliberalization assumes the public 'goodness' of privatization, lean government and deregulation through the implementation of "competitive regimes of resource allocation" (Peck and Tickell, 2002, 394). The value of competitiveness, and the related managerial tool of performance measurement, play a fundamental role in the neoliberal ideology (Kornberger and Carter, 2010; Santangelo, 2016), thus becoming a constitutive element of the smart city utopia. Kornberger and Carter (2010) suggest that the diffusion of city rankings that measure the "smartness" of cities is an example of the disciplinary and normalizing power of neoliberalism to generate competition among cities by transforming their differences in deviances from a norm of smartness assumed to be the best practices. Another example is the Smart Cities Stakeholder Platform initiated by the European Commission (Smart City Project, 2013) which places the urban paradigm of smart city at the centre of European policies for the coming years. The availability of European financial resources earmarked for smart cities projects strongly impacts the allocation policies of cities hit by the economic crisis (Cocchia, 2014) and expose them to international competition.

This process of "neoliberalization of the urban space" (Brenner and Theodore, 2002b) has also led to the diffusion of "'networked' forms of governance based upon public-private partnerships; 'new public management' strategies; privatization and competitive contracting of municipal services" (Guarneros-Meza et al., 2010, 116). A key idea of this neoliberal restructuring of the public sector is that governments are no 
longer called upon to govern, command and control but to "steer" (Bevir and Rhodes, 2003, 46). Accordingly, the underlying assumption of the smart city paradigm is that "solving societal problems is not merely a question of developing good policies but much more a managerial question of organizing strong collaboration between government and other stakeholders" (Meijer and Bolívar, 2015,3).

According to the critical scholars of the neoliberal ideology (Brenner and Theodore, 2002a; GuarnerosMeza and Geddes, 2010), there is an increasing concentration of urban power in the hands of a few political and business elites in European cities (Blanco, 2015, 124). The financial austerity measures imposed upon cities force them to rely more and more on private and local sources of revenue (Brenner and Theodore, 2002b). This results in the adoption of a profit-oriented approach and in an increasing involvement of private actors, holders of innovation and technological knowledge. This involvement raises relevant issues (Hollands, 2015; Vanolo, 2014). First, it results in an increasing call for technological solutions, even when something very different is needed (Hollands, 2015; Taylor, 1991, 6). Second, this business-led development of smart city leads to a "corporate vision of smartness" (Hollands, 2015, 2) and to the primacy of the economic logic over political and social issues. Urban development itself risks to be driven by profit seeking: "like businesses, cities also have to be resilient and able to generate revenues" (Rayner, 2015). Thus, the impact of the smart city is often expressed in monetary terms:

"A 'smarter' country is worth up to 10 points in GDP annually." (ABB, 2012)

There are clear steps that cities can take, such as getting assistance in leading projects, improving planning, and achieving a better understanding of the cost and benefits of a smart city. As they undertake the steps recommended here, they can move beyond the current barriers and start to capitalize on the benefits of a smart city. (Cisco, 2014; emphasis added)

Finally, this neoliberal-based smart city utopia may lead to a privatization of decision-making and an exercise of power insulated from democratic accountability (Swyngedouw, 2005). As observed by Lehman (1999, 234), "it seems that the community's environmental and social relationships are deferred to corporations, all competing in a deregulated and increasingly transnational market place." Thus, within the smart city paradigm, "no longer would government be the sole monopoly provider [...] private purveyors would create competition for government service delivery contracts - bringing a market into public service delivery"(Warner, 2012, 538). Given their great influence on public policies, "city leaders are also accountable and should be held accountable in the pursuit of the status of "smart city" (Glasmeier and Christopherson, 2015, 10). This neoliberal marketization of the public sphere challenges the traditional mechanisms of democratic accountability enacted through the ballot box and political representation (Brenner and Theodore, 2002b), insofar as the private actors leading the way towards the smart city are not democratically elected (Vanolo, 2014).

\section{Method and methodology}

Building on Habermas (1971), this study proposes critical hermeneutics as a valuable methodology for unmasking ideology. Hermeneutics is the use of interpretation to explain an object of study (Taylor, 1985). It originally referred to the discipline of interpreting biblical and ancient classics, with the aim of grasping the underlying meanings of texts, moving from the parts to the whole (Alvesson and Skllowing, 2009). This process leads to a "hermeneutical circle" as interpretation requires a movement back and forth between the parts and the whole of the text to deepen the overall understanding (Thompson, 1990). 
With Ricoeur (1986), Habermas places hermeneutics at the center of critical social science, the goal of which is emancipation by means of a critique of ideology (Dyer, 2010). Our study develops a critique of smart city ideology that shows "the ways in which meaning serves to establish and sustain relations of domination" (Thompson, 1990, p. 56). Differing from prior hermeneutical approaches (Gadamer, 2004), a critical hermeneutics or "depth hermeneutics" (Habermas, 1971, p. 218) attempts to reveal, through a process of understanding, systems of distortion (Ricoeur, 1986) and structural deformation of communication (Habermas, 1971).

Language produces and conveys ideology, ideology implying a "structural deformation of communication" (Habermas, 1971). Thus, language can be partaken of or used by institutional power to dominate:

Language is also a medium of domination and social force. It serves to legitimate relations of organized power. Insofar as the legitimation of power relations ... are not articulated ... language is also ideological (Habermas, 1990, p. 239).

Consequently, we conceive languages not as formal transcendental structures, but in specific historical contexts (Thompson, 1984), as "social philosophies, penetrated by a system of values inseparable from living practice and class struggle" (Bakhtin, 1984, p. 470).

We suggest that only an interpretative circle that enriches meta-narratives of smart city with the complexity of real cities, and interpret these cities in the light of the above theoretical explanations and conceptualizations may grasp the meaning of the smart city paradigm. This hermeneutic approach requires that, in our understanding of the smart city paradigm, we analyse the narrative of smart city and its role in sustain the neoliberal ideology. Hence, this study supports the theoretical arguments described in the previous sections by analyzing the display of smart city ideology in a specific empirical setting. Specifically, we chose the city of Genoa as a convenient case due to its increasing involvement in smart cities initiatives and because it symbolizes more than other cities the neoliberal roots of the smart city utopia and its shortcomings.

We draws from many sources of data in order to provide an overview of the development of the smart city utopia in the Genoa case. The study focuses on the years from 2010 - when an association was formed to translate the smart city utopia- to the present, and relies on local and national documents, including administrative documents, newspaper articles, discourses, public speeches, and minutes of the Genoa's city council. European and international documents and newspaper articles have been also included in the analysis to show that the Genoa's case conforms to a trend of global diffusion.

\section{The neoliberal ideology behind utopia: the Genoa case.}

Genoa, the capital of Liguria, is the largest seaport in Italy and one of the European biggest city in the Mediterranean. Once part of the Italian industrial triangle together with Milan and Turin, Genoa's economy has been bolstered for years by the shipyards and steelworks sectors (Guano, 2015).

Starting from the '70s, the exposure to international business competition and the more recent recession forced the Genoa's administrations to look for new economic opportunities (Galdini, 2005). Capital of European Culture program of 2004, the city was granted the UNESCO World Heritage status in 2007 and has been protagonists of a series of promotional events in the last decades, such as the World Cup in 1990, the Colombian Expo of 1992, the G8 summit in 2001 (Guano, 2015). 
The smart city utopia emerged as expression of this urban regeneration strategy. Recognized as one of the top 15 smart cities in Italy (Galbraith, 2014), in June 2011, Genoa was the only city in Europe to be awarded funding in three different projects (the projects TRANSFORM, CELSIUS, and R2CITIES) in response to the call for proposals on "Smart Cities and Communities Initiatives". Furthermore, the city of Genoa is the only Italian municipality that, in 2010, established an association to govern the smart city strategy in collaboration with national state-owned enterprises (Enel Distribuzione) and the University of Genoa (Galbraith, 2014). Public actors, business companies, and not-for- profit organizations are invited to join the Genoa Smart City Association (GSCA) to contribute to the transformation of Genoa into a smart city.

The economic and political actors that comprise GSCA are those in charge not only of "planning the city of the future" (GSCA website), the smart city utopia, but they also set the direction of public policies and public money (EU funds for smart cities projects). Overall, GSCA is made up of $21.6 \%$ large companies (e.g., Siemens, Selex Elsag, Ansaldo Energia, Ericsson, ABB); 47.6\% SMEs, 7.9\% trade associations, 5.8\% not-forprofit organizations, while public bodies and research bodies represent respectively only $12.6 \%$ and $4.5 \%$ (Galbraith, 2014, 141).

In line with the neoliberal principles, the role of the municipality in the process toward smartness involves "less government (or less rowing) but more governance (or more steering)" (Bevir and Rhodes, 2003, 46). In the words of Gloria Piaggio, director of the Smart City programme at the Genoa municipality: "once seen as mere bureaucratic agencies, municipalities are now shifting toward acting as planning offices" (Ulivieri, 2012). GSCA appears as a "polycentric multi-sectorial stakeholder context" (Antiroikko et al., 2011, 3). In this context, the municipality relies on a network of organizations with multiple competencies in order to achieve public policy goals. The traditional hierarchical governance is sacrificed in the name of interdependent horizontal collaborations between public and private actors (Almquist et al., 2013).

Changing national policies reflect this trend. To promote a more effective management of urban areas, Law 134/2012 (art. 12Bis) appointed the Inter-Ministerial Committee for Urban Policy (CIPU) in charge of setting the Urban Agenda in accordance with that suggested by the European Commission on the cohesion policy 2014/2020 (Sanseverino, 2014). The document "Priority methods and contents concerning Urban Agenda," presented by the Ministry for Territorial Cohesion, indicates the smart city initiative as an area where new forms of collaboration and financing between public and private actors are emerging. The document suggests that the national Urban Agenda should foster these emerging partnerships by promoting the development of a "concerted and consensual" city planning (CIPU, 2013, 20). The document also shows that this model of city planning implies a limitation of the direct responsibility of the municipalities over the projects implemented in their territories due to the multiplicity of actors involved. For example, considering the 24 cities that manage the $22 \%$ of the entire amount of the European Regional Development Fund ERDF ( 6 billion euros), municipalities have direct responsibility for implementation of the $25 \%$ compared to the $30 \%$ managed by business companies and other private actors (CIPU, 2013, 35).

In this new changing environment, the role of the municipality of Genoa is still unclear and indefinite. In this respect, consider the meaningful exchange between city councilors Giovanni Vassallo and Clizia Nicolella, members of the political majority, during a meeting of the city council:

Vassallo: "it is not the municipality that should do... that should make policies... if companies do not have a specific business interest in it... we are unable to make great strides." 
Nicolella: "I strongly disagree with the idea that business companies should make policies... business companies should follow the policies decided by the municipality [...] the role of the municipality in articulating and orienting the projects is essential [...] Is the municipality powerful enough to direct the orientation of these powerful business interests?" (Minutes of City Council Meeting, 08 May 2013, translated by the authors)

In line with national and international directives on city planning, the governance of GSCA shows the ascent of new actors (the new dominant class) in charge of developing the city of the future, the smart city utopia. The mission of GSCA is "to rethink the concept of the city, pursuing the concept of a concrete utopia in an urban space at human scale" (GSCA website, emphasis added). The rhetoric of smart city ideology is here fully deployed. An entrepreneurial ethos coupled with a celebration of competitiveness governs and orients the GSCA policies:

The reference to intelligence comes from the use of a system which is able to take into account different variables and predict the effects of actions taken in both planning and management. [...] Every action is related to an energy demand; in a smart city this relationship can be measured and made transparent [...] the Smart City must be able to measure out the right amount of risk even in policy-making [...] it is necessary to put in place measures that enable development and positioning at a competitive level. [...]The first keyword relating to the Smart City is planning. (GSCA website)

This call for measurement and competition, reveals the legacy of the neoliberal view of the smart city programme. The smart ideology discourse is also in place to justify and legitimize the financial funds management of GSCA, which fosters a competitive environment:

All lines of financing are being redirected in a smart sense, introducing a rewards system in tender competitions for those who employ innovative technologies, methods of energy savings and contribute to improvements in the quality of life. (GSCA website; emphasis added)

Smartness is identified with a general concept of innovation and with a substantial use of technologies precisely those technologies that the economic actors involved in this process of enhancing the public good are able to provide. The benefits that these economic actors can obtain from this involvement are huge. The global smart city technology market is expected to be worth more than $\$ 27.5$ billion annually by 2023 , compared to $\$ 8.8$ billion in 2014 (Woods and Gartner, 2013).

However, this utopian description of Genoa as a "living lab" serves to conceal another reality: that Genoa as a city subject to an indiscriminate urbanization that have dramatically increased the geohydrological risk of the area.

In the last 40 years, the region of Liguria has been one of the regions most affected by landslides and floods (Research Institute for Hydrogeological Protection IRPI-CNR, 2015). Important inundation events affected the city of Genoa in October 1970, September 1992 and September 1993 (see Tab. 1). 
Tab. 1: Impacts from the major storm events in Genoa from 1970. Source: Faccini et al. (2015)

\begin{tabular}{|c|c|c|c|}
\hline $\begin{array}{l}\text { Date of major storm } \\
\text { event }\end{array}$ & Storm-related deaths & Damage losses* & Other damages \\
\hline 7 October 1970 & 44 fatalities ( 25 within Genoa) & EUR 19 billion & 1000 people homeless; 50000 people unemployed \\
\hline 27 September 1992 & 2 fatalities & EUR 125 million & 250 people homeless \\
\hline 23 September 1993 & 7 fatalities & EUR 800 million & $\begin{array}{l}100 \text { people homeless; impact on historic structures } \\
\text { and significant construction projects }\end{array}$ \\
\hline 4 October 2010 & 1 fatality & EUR 96 million & 20 people homeless \\
\hline 4 November 2011 & 6 fatalities & EUR 155 million & 150 people homeless \\
\hline 9-10 October 2014 & 1 fatality & EUR 250 million & 250 people homeless \\
\hline
\end{tabular}

* Original cost reported in current Euro.

In October 2014, after torrential rains, the Genoa's rivers, Bisagno, Fereggiano and Sturla, flooded causing one fatality. The damage to public infrastructure was estimated at some 250 million euros. In the aftermath, the international news agency Reuters commented: "the impact of storm and landslide damage has been exacerbated in recent years by unregulated building and the poor state of some public infrastructure" (Balsomini, 2014). Despite the climate change plays a key role with respect to geohydrological risks, "the complete and irrational urbanization of valley floors seems, however, the most striking aspect" (Faccini et al., 2015, 2648; see Fig. 1).
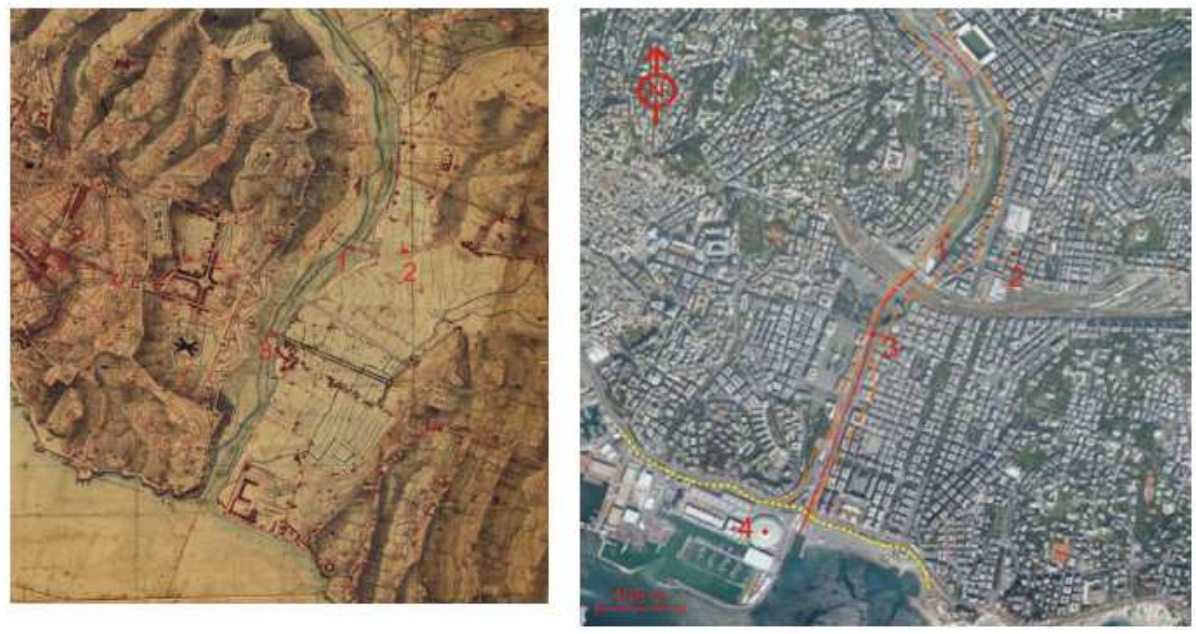

Fig. 1: Final stretch of the Bisagno stream at the beginning of the 19th century (left panel) and in the present day (right panel). Source: Faccini et al. (2015)

This process of mismanaged urbanization dates back to the 60s:

"At that time, not only did Genoa have to surrender its pleasant western seaside neighborhoods to shipyards and highly polluting factories, but its cityscape was also marred by a rationalization of urban space (see Lefebvre 1978) that consistently prioritized industrial production and the interests of developers over residents' wishes and needs" (Guano, 2015, p. 164).

The deindustrialization process that interested the area since the '80s has not coincided with a limitation of this phenomenon that remains one of the most compelling problem of the area (Sansa and Preve, 2008). The issue of hydrogeological instability is one of the challenges that the smart city utopia is planning to solve. Technology and innovation are welcomed as the panacea of all troubles. Meaningful in this regard is the declaration made by Gloria Piaggio in an interview with a national newspaper: 
[The journalist]: Will the smart city also improve the ability of the area to withstand these weather events?

[Gloria Piaggio]: The hydrogeological is one of the major themes [hemes [themes that if there were technologies such as sensors or communication with citizens via smartphones...we could have avoided the victims. Selex and Toshiba are working on how to monitor the area and prevent similar incidents, and we participate in the European project HARMONISE, which has just this purpose. (Ulivieri, 2012)

Actually, the ClouT (Cloud of Things for empowering the citizen clout in smart cities), a joint EuropeanJapanese ICT project, launched in July 2013 included Genoa among its participants with the development of a pilot application that should help citizens when facing emergencies. The application, called "I don't risk", obtains environmental and weather data from sensors and provides information through mobile devices to the citizens and to the civil-protection agency of Genoa in order to reduce concrete risk in critical situations. Similarly, the HARMONISE project aims at developing "sensor placement tool for security systems design" (SELEX Elsag, website).

While these solutions can help reduce concrete risk for citizens in critical situations, they fail to provide the municipality with sound long-term preventive mechanisms that could collectively address the causes of the flood, such as poor urban planning. The business-led development of the smart city utopia favor the deployment of consequences-oriented technological solutions, in so doing diverting the attention away from the causal roots of the geohydrological risk (i.e. aggressive urbanization), the latter requiring a coherent policy development process. The Genoa case shows how "the current dominance of supply-driven smart city solutions often results in smart city strategies that are disconnected from their social context and fail to tackle a city's problems in a cohesive way" (Angelidou, 2015, 104).

In addition, the contemporary face of ideology that sees this growing involvement of private actors in the development of public policies creates more than a few problems in terms of democratic participation to the definition of the future city and public accountability (Smyth, 2012; Bovens, 2007). It is meaningful that in Italy, where the smart city ideology is more and more pervasive, only one person out of five knows the meaning of the term 'smart city' (ABB, 2012). With respect to the case of Genoa, it is worth noting that the Statute of the Genoa Smart City Association does not refer to any form of public consultation for the selection and implementation of the smart projects. Moreover, a proposal to revise the Statute in this spirit has been rejected by the City Council. A participant explained:

"It's complicated to ask the companies to do certain things because this association is not the Municipality of Genoa, is made by the Municipality of Genoa with the participation of a majority of third parties ... We cannot ask these companies to make participatory processes" (Minutes of City Council Meeting, 14 May 2013, translated by the authors)

Furthermore, do the private interests of the economic actors that are part of GSCA lead necessarily to an enhancement of the public good? Are they required to be accountable to the Genoa's citizens they declare to serve? Quoting a speech of Tony Benn to the House of Commons (1998), the journalist E. Heathcote has effectively explained this issue: "What power have you got? Where did you get it from? In whose interests do you exercise it? To whom are you accountable? And how can we get rid of you? Once, those questions needed to be asked about governments; now they need to be asked of the global tech corporations who wield extraordinary lobbying power" (Heathcote, 2015). Democratic elections ensure the right of 
communities to ask their elected representatives to account for how the public money is spent (Barton, 2006). On the contrary, no accountability mechanisms exist requiring the new actors of the smart city to be accountable to its citizens.

\section{Conclusions}

This study started with the analysis of the existing definitions of the smart city concept. Our first aim was to show how the discourse on smart city constructs the collective imagination of a common utopia. The promoters of the smart city paradigm used the term utopia because of its symbolic power. Indeed, this term recalls the revolutionary and emancipative effort of oppressed groups. Our paper adds to previous critical studies on the topic of smart cities (Hollands, 2015; Hollands, 2008; Greenfield, 2013; Vanolo, 2013; Kitchin, 2014; Marvin et al., 2015), by calling into question this definition of smart city as a concrete utopia and highlighting the neoliberal ideas and values underpinning this concept and how these are translated into practice.

The paradox of Genoa, labelled "smart city" but protagonist of aggressive urban planning policies, shows the shortcomings of the smart city utopia and the way in which neoliberalism values influence its translation into practice. The smart city utopia serves the interests of big multinational ICT companies, while neglecting the need of political (not only technological) answers to public and common interests. It conveys neoliberal values and shapes urban problems by making visible some aspects while at the same time obscuring others. Thus, the emphasis on fancy technological solutions risks diverting attention away from issues, such as the broad impact of urbanization, that require a long-term "urban planning-based" approach driven by the political and ethical willingness of municipalities.

To the neoliberal ideology calling for an increasing involvement of corporations in the definition and enactment of public policies, we oppose the need of a concrete utopia (Bloch, 1995) created and nourished by the civil society. What the promoters of smart city claim to be a concrete utopia prove to be on the contrary an abstract utopia, a sterile and decontextualized narrative that preserve existing relations of power, rather than challenging them. A concrete utopia should not result from a top-down imposition of "grand utopian visions of the 'good' city and 'good' citizenship" (Amin and Graham, 2004, 423), but from a democratic debate about public interest and from the development of a public space where citizens can share more than individual preferences and utility (Malsch and Paracini, 2013). Thus, this utopia would combine the aspirations of two alternative models, the progressist, "looking to the future and inspired by a vision of social progress" and the culturalist, "nostalgic in outlook [and] inspired by the vision of a cultural community" (Choay, 1969, 31).

The business-led smart city utopia transforms the "political subjectivities of citizens" (Vanolo, 2016, 35). It is meaningful that the smart city discourse describes citizens as consumers rather than as political actors: "when developing a new smart city service, an extreme focus on the customer is needed" (Smart Circle Org. website). Citizens, as 'consumers' are required to express their opinions on the quality of services, as 'data providers', are both unconsciously and voluntarily involved in the ideation of these services. As expressed by Paola Testa, research director at Cittalia - European Research Center for Cities and Municipalities, there needs to be an "engagement of the citizens in addressing choices and decisions, both through sensors or the sharing via social network" (II Sole 24 ore, 11 November 2012). On the contrary, we believe that citizens can play a more active role not only in shaping the characteristics of this utopia, but also in providing ideas for technological innovation, through civic hacking initiatives, and bringing about alternative forms of citizens participation and engagement (Vanolo, 2016; Granier and Kudo, 2016; Capra, 2016). The contingent and temporary character of these initiatives risks to jeopardize their democratic potential 
(Lodato and DiSalvo, 2016), hence the effort to stabilize over time "a specific sets of relationships between participants, skills, expectations and technologies" (Perng and Kitchin, 2015, 14) and "a commitment to establishing the contextual effectiveness of a solution" (Perng and Kitchin, 2015, 14) are necessary conditions for the development of a democratic-inspired utopia.

As Crossley $(2004,89)$ noted, "the public sphere is one place where we can make a strong claim for the necessity of undistorted communication." This process involves the development of "counterpublics" (Asen, 2000, 424; Fraser, 1990), discursive arenas where "emergent collectives" (Asen, 2000, 438) formulate alternative discourses and norms to reconfigure existing systems of power; hence, the necessity of overcoming the idea of a monolithic public sphere by recognizing and fostering a multiplicity of public spheres.

In this process, cities have a role to play in enabling these counter-discourses through a wider discursive engagement of citizens in the development of the smart city utopia. The role of cities is to understand and listen to the counter-discourses of citizens, involving them in the definition of values and common goals and not only in the definition of services already settled in the dominant public sphere. 


\section{References}

ABB, The European House-Ambrosetti (2012), Smart Cities in Italia: un'opportunità nello spirito del Rinascimento per una nuova qualità della vita. Retrieved 16 June 2015, from www.ambrosetti.eu

Adams, R. 2010. Longing for a Greener Present: Neoliberalism and the Eco-city. Radical Philosophy 163.

Ahvenniemi, H., Huovila, A., Pinto-Seppnello spirito del Rinascimento pWhat are the differences between sustainable and smart cities?. Cities, 60, 234-245.

Almquist, R., Grossi, G., van Helden, G. J., and Reichard, C. (2013). Public sector governance and accountability. Critical Perspectives on Accounting, 24(7itical Perspe

Althusser, L. (1971). Ideology and ideological state apparatuses (notes towards an investigation). In Bren Brewster (Trans.) Lenin and philosophy and other essays, New York: Monthly Review Press.

Anthopoulos, L. (2016). Smart utopia VS smart reality: Learning by experience from 10 smart city cases. Cities.

Alvesson, M., and Skvesson,, K. (2009). Reflexive methodology: New vistas for qualitative research. Sage.

Amin, A., and Graham, S. (1997). The ordinary city. Transactions of the Institute of British Geographers, 22(4), 411-429.

Angelidou, M. (2015). Smart cities: A conjuncture of four forces. Cities, 47, 95-106.

Angelidou, M. (2014). Smart city policies: A spatial approach. Cities, 41, S3-S11.

Antiroikko, A.V., Bailey, S.J., and Valkama P. (2011) Innovations in public governance in the western world. In A.V. Antiroikko, S.J Bailey, P. Valkama, (Eds.). Innovations in public governance. Amsterdam: IOS Press.

Anthopoulos, L. (2016). Smart utopia VS smart reality: Learning by experience from 10 smart city cases.cCities.

Asen, R. (2000). Seeking the Seeking toin counterpublics. Communication theory, 10(4), 424-446.

Balsomini, P. (2014). One dead in Italy as floods sweep through Genoa. Reuters. Retrieved 23 October 2015, from http://www.reuters.com/article/2014/10/10/uk-italy-flood-idUSKCNOHZ1EH20141010

Baron, M. (2012). Do we need Smart Cities for Resilience? Journal of Economics \& Management, 10, 32nal o

Barton, A. D. (2006). Public sector accountability and commercial-in-confidence outsourcing contracts. Accounting, Auditing \& Accountability Journal, 19(2), 256A271.

Bakhtin, M. (1984). Rabelais and his World (Vol. 341). Indiana University Press.

Benn T. (1998). Speech to the House of Commons, 16 Nov 1998 (Hansard volume 319 column 685 fom 7.20pm, Debate on: European Parliamentary Elections Bill).

Bevir, M., and Rhodes, R. (2003). Interpreting British Governance. Psychology Press.

Blanco, I. (2015). Between democratic network governance and neoliberalism: a regime-theoretical analysis of collaboration in Barcelona. Cities, 44, 123-130.

Bloch, E. (1995). The principle of hope. Cambridge, MA: MIT Press.

Bovens, M. (2007). Public accountability. In E. Ferlie, L. Lynn, and C. Pollitt, (Eds.). The Oxford handbook of public management. Oxford Handbooks Online.

Brenner, N., and Theodore, N. (2002a). From the he alocalism he the spaces of neoliberalism. In N. Brenner and N. Theodore (Eds.), Spaces of neoliberalism: Urban restructuring in North America and Western Europe (pp. v of neoliberalism: Urban

Brenner, N., and Theodore, N. (2002b). Cities and the geographies of "actually existing neoliberalism". Antipode, 34(3), 349-379.

Campanella, T. (1602). The City of Sun.

Capra, C. F. (2016). The Smart City and its Citizens: Governance and Citizen Participation in Amsterdam Smart City. International Journal of E-Planning Research (IJEPR), 5(1), 20-38.

Caragliu, A., Del Bo, C., and Nijkamp, P. (2011). Smart cities in Europe. Journal of urban technology, 18(2), 65 of 
Carvalho, L. (2015). Smart cities from scratch? A socio-technical perspective. Cambridge Journal of Regions, Economy and Society, 8(1), 43-60.

Choay, F. (1969). The Modern City: Planning in the 19th Century. Trans. by Marguerite Hugo and George R. Collins (New York: Braziller, 1969).

CIPU 43-60.ournal of Regions, Economy and Societypective. perspective. ective. isting neoliberalism". sis of collaboration in Barcelona. kama, (Eds.).

Cisco (2014). White paper. Smart City Readiness: Understand the Issues to Accelerate the Journey. Retrieved 12 March 2015, from http://www.cisco.com/web/strategy/docs/smart-city-wp732985.pdf.Cocchia, A. (2014). Smart and digital city: A systematic literature review. In Smart City (pp. 13-43). Springer International Publishing.

Cretu, L. G. (2012). Smart Cities Design using Event-driven Paradigm and Semantic Web. Informatica Economica, 16(4), 57ca,

Crossley, N. (2004). On systematically distorted communication: Bourdieu and the socio franalysis of publics. The sociological review, 52(s1), 88-112.

Datta, A. (2015). New urban utopias of postcolonial India: 'Entrepreneurial urbanization 'in Dholera smart city, Gujarat. Dialogues in Human Geography, 5(1), 3-22.

Dyer, J. (2010). Hermeneutics. International Encyclopedia of Education (Third Edition), 63-68.

Eagleton, T. (1996). Marxist literary theory. Oxford: Blackwell Publishers.

Faccini, F., Luino, F., Sacchini, A., Turconi, L., and De Graff, J. V. (2015). Geohydrological hazards and urban development in the Mediterranean area: an example from Genoa (Liguria, Italy). Natural Hazards and Earth System Sciences, 15(12), 2631-2652.

Ferrara, E. (2014). Si chiama "Rinascimento digitale" nel piano anche il wifi in tutte le scuole. La $\begin{array}{lllll}\text { Repubblica.it. } & \text { Retrieved } 20 & \text { October } & \text { 2015, from }\end{array}$ http://ricerca.repubblica.it/repubblica/archivio/repubblica/2014/10/24/si-chiama-rinascimentodigitale-nel-piano-anche-il-wifi-in-tutte-le-scuoleFirenze05.html?ref=search

Fraser, N. (1990). Rethinking the public sphere: A contribution to the critique of actually existing democracy. Social text, 56-80.

Fuggetta, A. (2012). La citt: A contribution to the critique of actually existing democracy.o-digitale-nelpiano-anch. Ecoscienza 5. Retrieved 03 March 2015, from http://www.arpa.emr.it/cms3/documenti/ cerca doc/ecoscienza/ecoscienza2012 5/ecoscienza $\underline{5 \quad 2012 \text { smart.pdf }}$

Gadamer, H. G. (2004). Truth and method. Bloomsbury Publishing USA.

Galbraith, B. (Ed.) (2014): Proceedings of the 9th European Conference on Innovation and Entrepreneurship (ECIE) 2014.

Galdini, R. (2005). Urban Regeneration Process. The Case of Genoa, an example of Integrated Urban Development Approach. Presented at the 45th Congress of the European Regional Science Association "Land Use and Water Management in a Sustainable Network Society" Vrije Universiteit Amsterdam 23-27 August 2005.

Glasmeier, A., and Christopherson, S. (2015). Thinking about smart cities. Cambridge Journal of Regions, Economy and Society 2015, 8, 3-12.

Granier, B., \& Kudo, H. (2016). How are citizens involved in smart cities? Analysing citizen participation in Japanese "Smart Communities". Information Polity, 21(1), 61-76.

Greenfield, A. (2013) Against the Smart City. New York: Do Publications.

Guano, E. (2015). Touring the Hidden City: Walking Tour Guides in Deindustrializing Genoa. City \& Society, 27(2), 160-182.

Guarneros-Meza, V., and Geddes, M. (2010). Local governance and participation under neoliberalism: Critical perspectives. International Journal of Urban and Regional Research, 34, 115natio 
Habermas, J. (1990). A review of Gadamer's Truth and Method. In Ormiston G. and Schrift A. (Eds.) The Hermeneutic Tradition: From Ast to Ricoeur (pp. 213-244). Albany: State University of New York Press.

Habermas, J. (1971) Knowledge and human interests. Beacon Press, Boston.

Hackworth, J. (2007), The Neoliberal City: Governance, Ideology, and Development in American Urbanism, Cornell University Press, Ithaca, NY.

Harvey, D. (2005). A Brief History of Neoliberalism. Oxford University Press, Oxford.

Harvey, D. (2000). Spaces of hope. Berkeley.

Harvey, D. (1989). From managerialism to entrepreneurialism: the transformation in urban governance in late capitalism. Geografiska Annaler 71 B.1, 3-17.

Heathcote, E. (2015). The dark heart of a smart city. GQ. Retrieved 20 October 2015, from http://www.gqmagazine.co.uk/comment/articles/2015-02/11/the-dark-heart-of-a-smart-city

Hertzler, J. O. (1923). The History of Utopian Thought. Macmillan, New York, pp. 1-2.

Hollands, R. G. (2015). Critical interventions into the corporate smart city. Cambridge Journal of Regions, Economy and Society, 8(1), 61-77.

Hollands, R. G. (2008). Will the real smart city please stand up? Intelligent, progressive or entrepreneurial? City, 12(3), 303-320.

II Sole 24 ORE, (2014). Smart trepreneurial? ity please stand upRetrieved 20 October 2015, from http://www.ilsole24ore.com/art/tecnologie/2014-12-17/smart-e-chi-smart-fa-citta-e-progetti063946.shtml?uuid=ABJQPwRC\&fromSearch

IBM (2011). IBM, for a Smarter Planet and Smarter Cities. Retrieved 10 September 2015, from http://www.ibm.com/developerworks/topics/smarter cities/

Kitchin, R. (2014). Making sense of smart cities: addressing present shortcomings. Cambridge Journal of Regions, Economy and Society, rsu027.

Kornberger, M., and Carter, C. (2010). Manufacturing competition: how accounting practices shape strategy making in cities. Accounting, Auditing \& Accountability Journal, 23(3), 325ng, A

Lehman, G. (1999). Disclosing new worlds: a role for social and environmental accounting and auditing. Accounting, Organizations and society, 24(3), 217-241.

Lodato, T. J., \& DiSalvo, C. (2016). Issue-oriented hackathons as material participation. New media \& society, 18(4), $539-557$.

Malsch, B., and Guénin-Paracini, H. (2013). The moral potential of individualism and instrumental reason in accounting research. Critical Perspectives on Accounting, 24(1), 74-82.

Marvin, S., Luque-Ayala, A., and McFarlane, C. (Eds.). (2015). Smart urbanism: Utopian vision or false dawn?. Routledge.

Meijer, A., and Boles on Accounting, $23 \mathrm{~d}$ Governing the smart city: a review of the literature on smart urban governance. International Review of Administrative Sciences.

Mora, L., Bolici, R., \& Deakin, M. (2017). The First Two Decades of Smart-City Research: A Bibliometric Analysis. Journal of Urban Technology, 1-25.

Neirotti, P., De Marco, A., Cagliano, A. C., Mangano, G., and Scorrano, F. (2014). Current trends in Smart City initiatives: Some stylised facts. Cities, 38, 25-36.

N 25-36.3, H., N H., N.3, L., and Melander, P. (2006). US (2006contractr ). US performance management models in a Danish environment. Financial Accountability \& Management, 22(3), 213-233.

Pamula, A., Gontar, Z., and Gontar, B. (2013). Deployment of Smart City Concept in Poland. Selected Aspects. Organizaciju Vadyba: Sisteminiai Tyrimai, 67, 39-51.

Peck, J. (2013). Explaining (with) neoliberalism. Territory, Politics, Governance,e1(2), 132-157.

Peck, J., and Tickell, A. (2002). Neoliberalizing space. Antipode, 34(3), 380-404.

Perng, S. Y., \& Kitchin, R. (2015). Solutions, strategies and frictions in civic hacking. Paper presented at MediaCity 5, 1st- 3rd May, 2015, Plymouth University, Plymouth, UK 
Rayner, K. (2015). Smart Cities Lead To Smarter Citizens. Forbes. Retrieved 20 October 2015, from http://www.forbes.com/sites/oracle/2015/01/16/smart-cities-lead-to-smarter-citizens/

Ricoeur, P. (1986). Lectures on Ideology and Utopia, New York: Columbia University Press.

Sansa F. e Preve M. (2008). Il Partito del cemento - Politici, imprenditori, banchieri. La nuova speculazione edilizia. Chiarelettere, Roma.

Sanseverino, E. R. (Ed.). (2014). Smart Rules for Smart Cities: Managing Efficient Cities in EuroMediterranean Countries (Vol. 12). Springer.

Santangelo, M. (2016). A (more?) intelligent city. Nóesis, 25(49_1), 65-77.

Smart City Project. (2013). Retrieved 20 October 2015, from http://ec.europa.eu/eip/smartcities/.

Smyth, S. (2012). Contesting public accountability: a dialogical exploration of accountability and social housing. Critical Perspectives on Accounting, 23(3), 230-243.

Söderström, O., Paasche, T., and Klauser, F. (2014). Smart cities as corporate storytelling. City, 18(3), 307320.

Swyngedouw, E. (2005). Governance innovation and the citizen: the Janus face of governance-beyond-thestate. Urban studies, 42(11), 1991-2006.

Taylor, C. (1991). The ethics of authenticity. Cambridge, MA: Harvard University Press.

Taylor, C. (1985) Philosophy and the Human Sciences, Cambridge, Cambridge University Press.

Thompson, J. B. (1990). Ideology and modern culture: critical social theory in the era of mass communication. Cambridge: Polity Press.

Van Dijk TA. Ideology. A multidisciplinary approach. London: Sage; 1998.

Vanolo, A. (2016). Is there anybody out there? The place and role of citizens in tomorrow's smart cities. Futures, 82, 26-36.

Vanolo, A. (2013). Smartmentality: The smart city as disciplinary strategy. Urban Studies.

Ulivieri, V. (2012). Smart city: a Genova approda la sostenibilitegyLaStampa.it. Retrieved 20 October 2015, from http://www.lastampa.it/2012/11/30/scienza/ambiente/green-news/smart-city-a-genovaapproda-la-sostenibilita-95Jksdj1f8z25zXBqEOm1l/pagina.html

Warner, M. E. (2012). Privatization and urban governance: The continuing challenges of efficiency, voice and integration. Cities, 29, S38-S43.

Watson, V. (2013). African urban fantasies: dreams or nightmares?. Environment and Urbanization, 26(1), 215ent .

Weber, M. (1905).The Protestant Ethic and the Spirit of Capitalism.

Wiig, A. (2015). IBM's smart city as techno-utopian policy mobility. City, 19(2-3), 258-273.

Woods, E., and Gartner, J. (2013). Navigant research leaderboard report: smart city suppliers, Navigant Consulting. Retrieved 10 September 2015, from https://www.navigantresearch.com/research/navigant-research-leaderboard-report-smart-citysuppliers. 